\title{
Acidification increases sensitivity to hypoxia in important forage fishes
}

\author{
Seth H. Miller*, Denise L. Breitburg, Rebecca B. Burrell, Andrew G. Keppel
}

Smithsonian Environmental Research Center, 647 Contees Wharf Road, Edgewater, Maryland 21037, USA

\begin{abstract}
Hypoxia (low dissolved oxygen [DO]) and $\mathrm{CO}_{2}$-induced acidification are important aquatic stressors that are exacerbated by anthropogenic nutrient inputs and are expected to increase in severity with increasing atmospheric $\mathrm{CO}_{2}$ and higher global temperatures. Understanding how species respond to changes in $\mathrm{DO}$ and $\mathrm{pH}$ is critical to predicting how climate change will affect estuarine ecosystems, including the extreme shallow margins of these systems, where factors such as respiration, photosynthesis, and tides create daily fluctuations of $\mathrm{DO}$ and $\mathrm{pH}$, and strong correlations between the 2 stressors. To determine how acidification affects the sensitivity to hypoxia of $2 \mathrm{im}$ portant forage fishes, the silversides Menidia menidia and $M$. beryllina, we recorded opercula ventilation rates, aquatic surface respiration (ASR, where fish breathe in the oxygenated surface layer during hypoxic events), and mortality as we lowered either DO or both DO and pH simultaneously. Fish subjected to low DO and low $\mathrm{pH}$ in the laboratory performed ASR and died at higher DO concentrations than fish subjected only to hypoxia. Additionally, fish beat their opercula slower, which may have contributed to the differences in ASR and mortality that we saw. These results indicate acidification can increase mortality under hypoxia not only directly but also indirectly by increasing vulnerability to predation during increased use of ASR.
\end{abstract}

KEY WORDS: Diel cycling - Estuaries - Menidia • Aquatic surface respiration $\cdot$ Ventilation

\section{INTRODUCTION}

Hypoxia and acidification are twin stressors that occur together worldwide, including in shallow water habitats such as estuaries. The generally high bio-

*Corresponding author: millerseth@si.edu

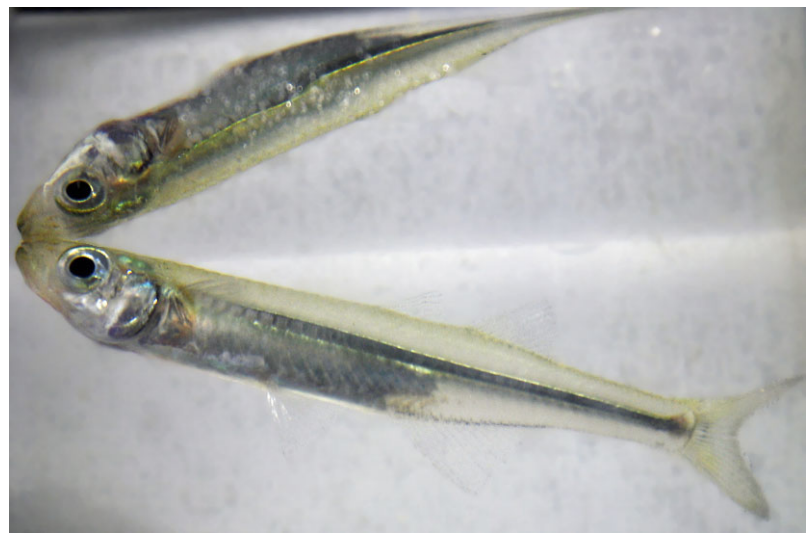

A fish meets its reflection as it comes to the surface to perform aquatic surface respiration under hypoxic conditions.

Photo: A. Smart

mass in estuarine habitats is often stimulated by anthropogenic nutrient loads (Rabalais et al. 2014), and leads to high rates of respiration that can simultaneously deplete dissolved oxygen (DO) and acidify water through the release of $\mathrm{CO}_{2}$ (Baumann et al. 2015, Breitburg et al. 2015). Both hypoxia and acidification are predicted to worsen as a result of rising temperatures and increasing atmospheric $\mathrm{CO}_{2}$ (Doney et al. 2012, Bopp et al. 2013). Higher temperatures boost respiration rates, decrease oxygen solubility, and alter hydrodynamics in ways that increase oxygen depletion, the release of respiratory $\mathrm{CO}_{2}$, and the impingement of deep, oxygen-depleted, high- $\mathrm{CO}_{2}$ waters into nearshore habitats (reviewed in Altieri \& Gedan 2015). Increasing acidification from biological processes, atmospheric $\mathrm{CO}_{2}$, and upwelling is predicted to reduce survival and growth of a wide range of marine and estuarine species

() S. Miller and the USA Government 2016. Open Access under Creative Commons by Attribution Licence. Use, distribution and reproduction are unrestricted. Authors and original publication must be credited.

Publisher: Inter-Research · www.int-res.com 
(Kroeker et al. 2010), and alter respiration-driven relationships between $\mathrm{DO}$ and $\mathrm{CO}_{2}$ concentrations (one molecule of $\mathrm{CO}_{2}$ produced for each molecule of $\mathrm{O}_{2}$ consumed), including in estuaries and the nearshore (Melzner et al. 2013). As hypoxic zones expand and $\mathrm{pH}$ simultaneously declines, understanding how these stressors interact is crucial (Frieder et al. 2012, Gobler et al. 2014).

Although hypoxia in some habitats persists for days to millennia (or even longer in the deep ocean), DO concentrations can fluctuate rapidly and repeatedly in the shallow waters of both marine and freshwater systems. In shallow estuarine waters, for example, day-night patterns of the net balance between photosynthesis and respiration, tides, weather, and restricted circulation can result in a large amplitude of fluctuations in $\mathrm{DO}$ and $\mathrm{pH}$ on diel or tidal cycles (Tyler \& Targett 2007, Baumann et al. 2015, Burrell et al. 2016). In some cases, DO can decline from near air-saturated to severe hypoxia concentrations in just a few hours, and $\mathrm{pH}$ fluctuations tend to be correlated (see Fig. 1).

Both hypoxia and acidification can cause a wide range of negative effects in aquatic organisms, ranging from mortality to altered behaviors (Rosa \& Seibel 2008, Breitburg et al. 2009, Ferrari et al. 2011, Miller et al. 2012, Munday et al. 2014). Many fishes exhibit aquatic surface respiration (ASR), during which fish breathe in the relatively more oxygenated surface layer in contact with the atmosphere (Kramer \& McClure 1982). Fish utilizing ASR under hypoxic conditions can survive longer than those prevented from accessing the surface layer (Smith \& Able 2003, Stierhoff et al. 2003), but may experience increased risk of predation, including predation by birds that are abundant in estuarine systems (Domenici et al. 2007). Fish also alter opercular movements to increase ventilation frequency or amplitude to increase water flow over the gills in response to hypoxia (Vulesevic et al. 2006). Increasing water flow in a high $\mathrm{pCO}_{2}$ environment, however, could potentially cause acidosis (Esbaugh et al. 2012) or otherwise disrupt the acid-base balance within fishes, possibly altering behaviors (Heuer \& Grosell 2014, Welch et al. 2014). Understanding how fish respond to hypoxia when simultaneously exposed to acidification will provide important insights into how fish currently behave in hypoxic environments and how they might respond to worsened conditions under future climate change (C. J. Gobler \& H. Baumann unpubl.). If acidification makes fish more sensitive to hypoxia, current regulatory minima on aquatic DO may be less protective than assumed, and acidification could have sub- stantial direct and indirect effects on fish populations and fitness.

To investigate how acidification affects ASR, ventilation, and survival in estuarine fishes exposed to hypoxic conditions, we conducted laboratory studies using 2 ecologically important forage species, the inland silverside Menidia beryllina and the Atlantic silverside $M$. menidia. These species have been used extensively as model organisms in studies of fundamental concepts of evolution and ecology (Billerbeck et al. 2000, Clarke et al. 2010) and to examine chemical toxicity and the resilience of an ecosystem to abiotic stressors (Fuller et al. 2004, Brander et al. 2013, Stefansson et al. 2013). Previous work has shown that they are sensitive to acidification and hypoxia during early life stages (Baumann et al. 2012, Murray et al. 2014), and that acidification could make them more sensitive to hypoxia (DePasquale et al. 2015), though the sensitivity of adults to these stressors is unknown. We used $\mathrm{pH}$ targets for experimental treatments because simultaneous measurements of $\mathrm{DO}$ and $\mathrm{pH}$ are much more common in the shallow estuarine habitats we mimicked than $\mathrm{DO}$ and $\mathrm{pCO}_{2}$ measurements. However, we estimate $\mathrm{pCO}_{2}$ and discuss the likelihood that effects are driven by $\mathrm{pCO}_{2}$, rather than $\mathrm{pH}$.

\section{MATERIALS AND METHODS}

\section{Fish collection and system parameters}

We collected adult Menidia beryllina (29-69 mm body length [BL]) and $M$. menidia (55-75 $\mathrm{mm} \mathrm{BL)} \mathrm{in}$ mixed schools using a $1.5 \mathrm{~mm}$ mesh beach seine in the Rhode and West subestuaries of Chesapeake Bay, USA under ambient conditions (Table 1) in September and October 2014 to test ASR behaviors. From April to July 2015, we collected adult M. beryllina (34-62 mm BL) and M. menidia (24-33 mm BL) in the same locations (Table 1) to test ASR behaviors; we also tested $M$. beryllina for ventilation rates. Fish were transported to the laboratory in aerated coolers and kept overnight in small schools in 751 tanks with flow-through, aerated estuarine water from the Rhode River at the Smithsonian Environmental Research Center (SERC), Edgewater, MD, USA.

To help characterize the carbonate system parameters during each trial, we measured total alkalinity weekly. Water samples were collected in treatment tanks using a syringe pump or off the SERC dock from a floating pump located $1 \mathrm{~m}$ below the water's surface. Samples were immediately syringe-filtered 
Table 1. Abiotic conditions and carbonate chemistry during field collections and laboratory trials using Menidia beryllina and M. menidia. In trials where we lowered dissolved oxygen (DO), mean low DO and mean low pH represent the mean lowest values at which fish died. No fish died in our control or $\mathrm{pH}$ control trials, so those mean low values represent the lowest values achieved over the duration of the trial. Conditions from field sites show the range of values recorded at sites during daytime collection trips. $\mathrm{n}=$ replicate aquaria (each with 3 fish) for aquatic surface respiration trials and replicate individuals for ventilation trials

\begin{tabular}{|c|c|c|c|c|c|c|c|c|}
\hline & $\begin{array}{l}\text { Mean low } \\
\text { DO }\left(\mathrm{mg}^{-1}\right)\end{array}$ & $\begin{array}{l}\text { Mean } \\
\text { low pH }\end{array}$ & Salinity & $\begin{array}{l}\text { Temp. } \\
\left({ }^{\circ} \mathrm{C}\right)\end{array}$ & $\begin{array}{c}\text { Alkalinity } \\
\left(\mu \mathrm{mol} \mathrm{kg}^{-1}\right)\end{array}$ & $\begin{array}{l}\mathrm{pCO}_{2} \\
(\mu \mathrm{atm})\end{array}$ & $\begin{array}{c}\mathrm{n} \\
\text { (M. beryllina) }\end{array}$ & $\begin{array}{c}\mathrm{n} \\
\text { (M. menidia) }\end{array}$ \\
\hline \multicolumn{9}{|c|}{ Aquatic surface respiration } \\
\hline \multicolumn{9}{|c|}{2014} \\
\hline Control & 7.95 & 8.00 & $10-13$ & $23-25$ & $1524-1642$ & $390-454$ & 6 & 3 \\
\hline Control DO, low pH & 7.95 & 5.95 & $10-13$ & $23-25$ & $1524-1642$ & $48955-56081$ & 12 & 3 \\
\hline Low DO, control $\mathrm{pH}$ & 0.64 & 8.00 & $10-13$ & $23-25$ & $1524-1642$ & $390-454$ & 14 & 3 \\
\hline Low DO, low $\mathrm{pH}$ & 0.92 & 6.34 & $10-13$ & $23-25$ & $1524-1642$ & $19904-22807$ & 16 & 3 \\
\hline Collection site & $6.5-8.0$ & $7.7-8.0$ & $11-12$ & $20-22$ & - & - & - & - \\
\hline \multicolumn{9}{|l|}{2015} \\
\hline Control & 8.05 & 8.02 & $7-9$ & $18-25$ & 1093-1148 & $288-307$ & 3 & 3 \\
\hline Control DO, low $\mathrm{pH}$ & 8.05 & 6.54 & $7-9$ & $18-25$ & 1093-1148 & 9299-10 201 & 3 & 3 \\
\hline Low DO, control pH & 0.74 & 8.02 & $7-9$ & $18-25$ & $1093-1148$ & $288-307$ & 17 & 9 \\
\hline Low DO, low pH & 0.85 & 6.64 & $7-9$ & $18-25$ & 1093-1148 & $7382-8096$ & 17 & 9 \\
\hline Collection site & $7.8-8.6$ & $7.5-7.8$ & $6-9$ & $19-24$ & - & - & - & - \\
\hline \multicolumn{9}{|l|}{ Ventilation } \\
\hline \multicolumn{9}{|l|}{2015} \\
\hline Control & 7.98 & 8.05 & 7.5 & 23 & 1142 & 286 & 6 & - \\
\hline Control DO, low $\mathrm{pH}$ & 7.98 & 6.60 & 7.5 & 23 & 1142 & 8767 & 6 & - \\
\hline Low DO, control pH & 1.21 & 8.05 & 7.5 & 23 & 1142 & 286 & 6 & - \\
\hline Low DO, low $\mathrm{pH}$ & 1.21 & 6.60 & 7.5 & 23 & 1142 & 8767 & 6 & - \\
\hline Collection site & $7.8-8.6$ & $7.5-7.8$ & $6-7$ & $18-19$ & - & - & - & - \\
\hline
\end{tabular}

through Whatman GD/X filters (pore size $0.45 \mu \mathrm{m}$ ) into $500 \mathrm{ml}$ Pyrex glass bottles and stored in the dark at $4^{\circ} \mathrm{C}$ prior to analysis.

Total alkalinity titrations were conducted in open vessels using a Mettler Toledo T-50 autotitrator, DGi 115-SC pH sensor, PT1000 temperature sensor, and $5 \mathrm{ml}$ burette with attached Inmotion Flex autosampler with waterbath rack kit and thermostat bath. Sample temperatures averaged $25.3^{\circ} \mathrm{C} \pm 0.1 \mathrm{SE}$ during titrations. Three Ricca high-precision NBS buffers (4.00, $7.00,10.00$ ) were used to calibrate the $\mathrm{pH}$ sensor prior to titrating samples. Total alkalinity was determined by Gran titration using $0.0998 \mathrm{~N} \mathrm{HCl}$ and $\sim 60.0 \mathrm{~g}$ of sample water. Sample pH was titrated to 3.0 and 14-16 points between $\mathrm{pH} 4.0$ and 3.0 were used for the Gran plot. Replicates of certified reference material seawater standards provided by Scripps Institution of Oceanography were titrated alongside samples to validate our methods (with an accuracy of $1.0 \mu \mathrm{mol} \mathrm{kg}$ seawater ${ }^{-1}\left(\mathrm{SW}^{-1}\right)$ and $\mathrm{SE}$ of $\left.\pm 1.9 \mu \mathrm{mol} \mathrm{kg} \mathrm{sw}{ }^{-1}\right)$. Alkalinity values were combined with salinity, temperature, and $\mathrm{pH}$ values recorded by our system using Durafet III $\mathrm{pH}$ probes (Honeywell International) to determine $\mathrm{pCO}_{2}$ values using the CO2SYS program (Brookhaven National Laboratory version 2.1).

\section{Aquatic surface respiration (ASR)}

After overnight acclimation, fish were placed into 751 treatment tanks in single-species groups of 3 individuals and allowed to acclimate for $1-3 \mathrm{~h}$ before trials began. Each treatment tank contained 2 airstones for gas delivery and was covered on 3 sides with contact paper to minimize disturbances. We ran 3 tanks of a single treatment simultaneously, and ran treatments in successive trials. We randomly assigned tanks 1 of 4 treatments: a benign control; a low $\mathrm{pH}$ treatment, during which we lowered $\mathrm{pH}$ but kept DO high; a low DO, control pH treatment; or a low DO, low pH treatment, where we lowered both stressors simultaneously.

During each trial, air, $\mathrm{N}_{2}$ gas, and $\mathrm{CO}_{2}$ gas were added using a continuous-feedback LabVIEW (National Instruments) routine receiving input from DO (Type III, Oxyguard International) and pH (Durafet III, Honeywell International) probes to control hypoxia and acidification conditions in each tank (Burrell et al. 2016). DO and $\mathrm{pH}$ were lowered steadily from normoxia to hypoxia until the last fish in a treatment died (approximately 2.5-3.5 h). Except for one test of pH-only effects on ASR and mortality, 
our low DO and low pH values mimicked those that currently occur in the field (Table 1, Fig. 1; MDNR 2014).

As each trial started, an observer was assigned to each tank and recorded the DO and $\mathrm{pH}$ when each fish first performed ASR, when all 3 fish in the tank consistently performed ASR (never leaving the surface), and when each fish died (counted as cessation of operculum movement). In 2015, observers also noted when each fish lost equilibrium, to provide an additional metric to quantify how fish responded. All observers recorded data on all treatments during the experiment and remained stationary throughout the trial to avoid altering fish behavior. The metric of consistent ASR was not recorded for $M$. menidia because we found that the species usually made repeated trips
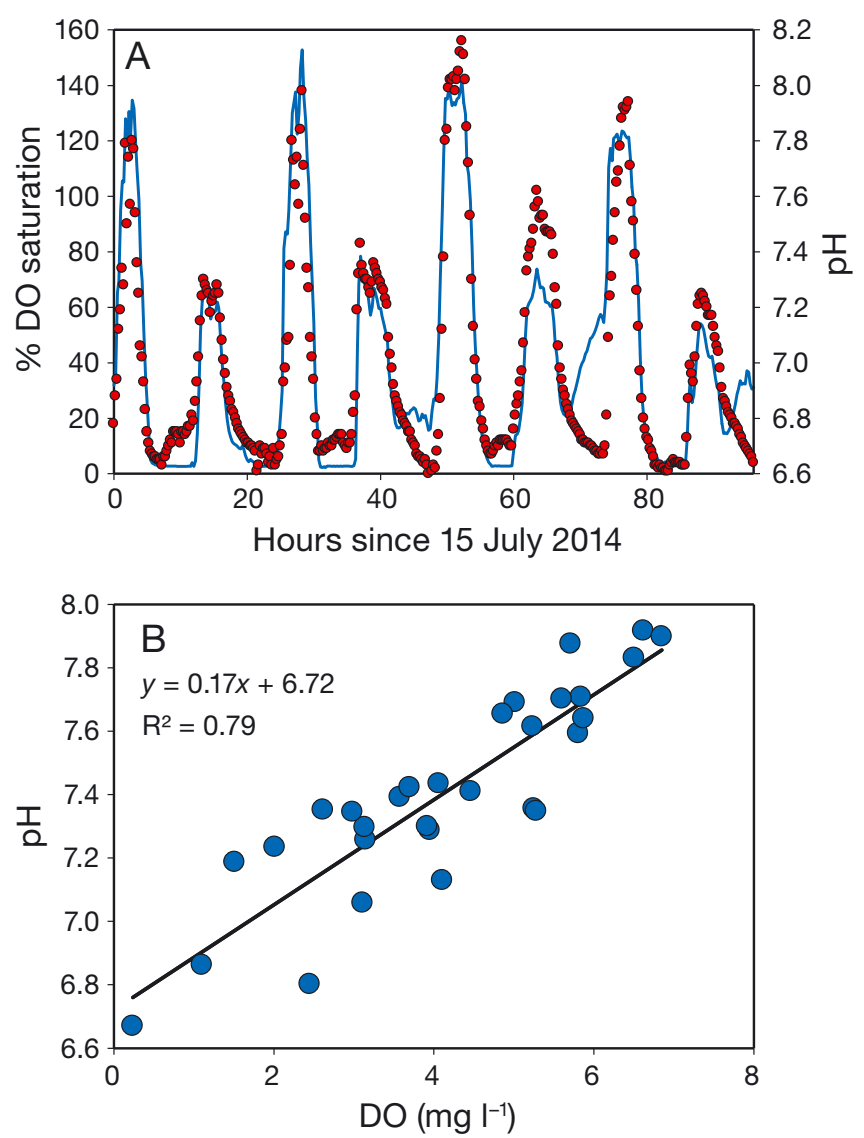

Fig. 1. Cycling of dissolved oxygen (DO) and $\mathrm{pH}$ in shallow mesohaline sites in Chesapeake Bay (modified from Breitburg et al. 2015, Burrell et al. 2016). (A) Four days of DO (solid line) and $\mathrm{pH}$ (circles) cycles in a saltmarsh creek in the Rhode River. The pattern is dominated by the tidal cycle with the steepest declines in $\mathrm{DO}$ and $\mathrm{pH}$ during nighttime ebb tides. (B) Relationship between mean daily minimum $\mathrm{DO}$ and mean daily minimum $\mathrm{pH}$ at mesohaline shallow water monitoring sites (from Breitburg et al. 2015; original data source MDNR 2014) to the surface to perform ASR, rather than remaining at the surface consistently performing ASR. This behavior has since been confirmed through several additional trials. Fish body lengths were measured to the nearest $\mathrm{mm}$ at the conclusion of each trial. We analyzed within-tank means for each metric, and tested for statistical differences between treatments using a 1-way ANOVA; all data met the assumptions of normality and homogeneity of variances. Preliminary ANCOVA tests indicated that fish length was unrelated to fish behavior or survival, so it was excluded from final analyses. All analyses were conducted with JMP 11 statistical software (SAS Institute).

\section{Ventilation rates}

After the overnight acclimation period, a single fish was placed into each observation box to be filmed for ventilation rate analyses. Each clear acrylic observation box $(8 \times 8 \times 11 \mathrm{~cm})$ had a plastic mesh bottom and open top, and was covered on 3 sides with white contact paper. Boxes were attached near the top of the inside of individual 751 aquaria filled with estuarine water at benign conditions, and gas lines with airstones were placed adjacent to the boxes to create water circulation and ensure conditions within the boxes were the same as in the larger aquaria. Fish were given a 30 min acclimation period before each trial began. Tanks were assigned to one of 4 treatments: benign control; low DO, control $\mathrm{pH}_{\text {; control }}$ $\mathrm{DO}$, low $\mathrm{pH}$; and low DO, low $\mathrm{pH}$ (Table 2). We ran 6 replicates of a single treatment simultaneously and ran treatments sequentially.

Fish were recorded for at least $2 \mathrm{~min}$ at the end of the initial $30 \mathrm{~min}$ acclimation period and during 3 subsequent intervals in each trial, using a Galaxy S4 (Samsung) or iPhone 6 (Apple) cellular phone attached to the end of a selfie stick. During preliminary trials, we found that using selfie sticks allowed us to film the fish closely with minimal disturbance. Our continuous-feedback software program modified the ratio of air, $\mathrm{N}_{2}$ gas, and $\mathrm{CO}_{2}$ gas to control hypoxia and acidification conditions in each tank according to the assigned treatments (Burrell et al. 2016). DO and $\mathrm{pH}$ were lowered (or held constant when appropriate) for $15 \mathrm{~min}$, followed by a $15 \mathrm{~min}$ interval during which all fish were recorded. Each fish was recorded 4 times over a period of $2.25 \mathrm{~h}$, including the initial acclimation period (Table 2). After the final recording, fish were removed from the observation boxes, measured to the nearest $\mathrm{mm}$, and weighed to the nearest mg. 
Table 2. Dissolved oxygen (DO) saturation and $\mathrm{pH}$ target values at each time point during ventilation trials for each of 4 treatments. Fish were filmed for at least 2 min during each interval. $n=$ number of replicates

\begin{tabular}{|c|c|c|c|c|c|c|c|c|c|}
\hline \multirow[t]{2}{*}{ Treatment } & \multirow[t]{2}{*}{$\mathrm{n}$} & \multicolumn{2}{|c|}{ Interval 1} & \multicolumn{2}{|c|}{ Interval 2} & \multicolumn{2}{|c|}{ Interval 3} & \multicolumn{2}{|c|}{ Interval 4} \\
\hline & & DO (\%) & $\mathrm{pH}$ & DO (\%) & $\mathrm{pH}$ & DO (\%) & $\mathrm{pH}$ & DO (\%) & $\mathrm{pH}$ \\
\hline Control & 6 & 100 & 8.05 & 100 & 8.05 & 100 & 8.05 & 100 & 8.05 \\
\hline Control DO, low pH & 6 & 100 & 8.05 & 100 & 7.50 & 100 & 7.00 & 100 & 6.60 \\
\hline Low DO, control pH & 6 & 100 & 8.05 & 75 & 8.05 & 50 & 8.05 & 25 & 8.05 \\
\hline Low DO, low $\mathrm{pH}$ & 6 & 100 & 8.05 & 75 & 7.50 & 50 & 7.00 & 25 & 6.60 \\
\hline
\end{tabular}

To analyze ventilation rates, each video was slowed to half speed and an observer counted the operculum beats per minute (BPM) in 3 haphazardly chosen $10 \mathrm{~s}$ periods using a computer widget to calculate rates (www.all8.com/tools/bpm.htm). To account for individual variability in basal ventilation rate, we report all data as percent change in BPM from initial. We tested for statistical differences among treatments using a repeated-measures ANOVA; all data met the assumptions of normality and homogeneity of variances. Fish lengths and weights had no significant effect on ventilation rates, so they were excluded from final analyses. All analyses were conducted using JMP 11 (SAS Institute).

\section{RESULTS}

\section{Aquatic surface respiration}

In both species in 2014, fish exposed to combined low $\mathrm{pH}$ and low DO initiated ASR and died at significantly higher DO concentrations than fish that were only exposed to low DO (Table 3, Fig. 2). Menidia beryllina also exhibited ASR consistently at a higher DO concentration when $\mathrm{pH}$ was simultaneously lowered than when only DO was reduced. None of the fish in our benign control or low pH-only treatments died during the trials (data not shown). Fish in the low pH-only treatment sporadically performed ASR, but only at dramatically lower $\mathrm{pH}$ levels than the fish in our low $\mathrm{pH}$ and low DO trials (Table 1).

In 2015, results were similar, and M. beryllina exposed to combined low $\mathrm{pH}$ and low DO first performed ASR, consistently performed ASR, and exhibited loss of equilibrium at higher DO concentrations than fish that were only exposed to low DO (Table 3, Fig. 2). Fish in the combined low $\mathrm{pH}$ and low DO treatment showed a trend towards dying at higher DO concentrations than fish only exposed to low DO, though it was marginally non-significant (Table 3 , Fig. 2). M. menidia exposed to combined low $\mathrm{pH}$ and
Table 3. ANOVA results for aquatic surface respiration (ASR) trials using Menidia menidia and M. beryllina in 2014 and 2015

\begin{tabular}{|lrrr|}
\hline Source & df & $F$ & \multicolumn{1}{c|}{$\mathrm{p}$} \\
\hline $\mathbf{2 0 1 4}$ & & & \\
M. menidia & & & \\
First ASR & 1,4 & 43.253 & 0.0028 \\
Death & 1,4 & 28.737 & 0.0058 \\
M. beryllina & & & \\
First ASR & 1,28 & 24.953 & $<0.0001$ \\
Consistent ASR & 1,28 & 5.452 & 0.0279 \\
Death & 1,28 & 11.940 & 0.0018 \\
& & & \\
2015 & & & \\
M. menidia & & & \\
First ASR & 1,16 & 7.220 & 0.0162 \\
Loss of equilibrium & 1,16 & 26.590 & $<0.0001$ \\
Death & 1,16 & 10.080 & 0.0059 \\
M. beryllina & & & \\
First ASR & 1,32 & 7.449 & 0.0121 \\
Consistent ASR & 1,32 & 4.269 & 0.0475 \\
Loss of equilibrium & 1,32 & 7.612 & 0.0117 \\
Death & 1,32 & 3.253 & 0.0807 \\
\hline
\end{tabular}

low DO first performed ASR, exhibited loss of equilibrium, and died at higher DO concentrations than fish that were only exposed to low DO (Table 3, Fig. 2).

\section{Ventilation}

Fish exposed to combined low $\mathrm{pH}$ and low DO performed fewer operculum BPM at low DO levels than fish exposed to only low DO $\left(F_{3,32}=38.02\right.$, $\mathrm{p}<0.0001$, Fig. 3). Fish exposed to only low pH performed the fewest operculum BPM at low $\mathrm{pH}$ levels out of any of our treatments, including the control $\left(F_{3,32}=38.02\right.$, $\mathrm{p}<0.0001$, Fig. 3). Control fish did not significantly change their ventilation rates over the duration of each trial (Fig. 3). 

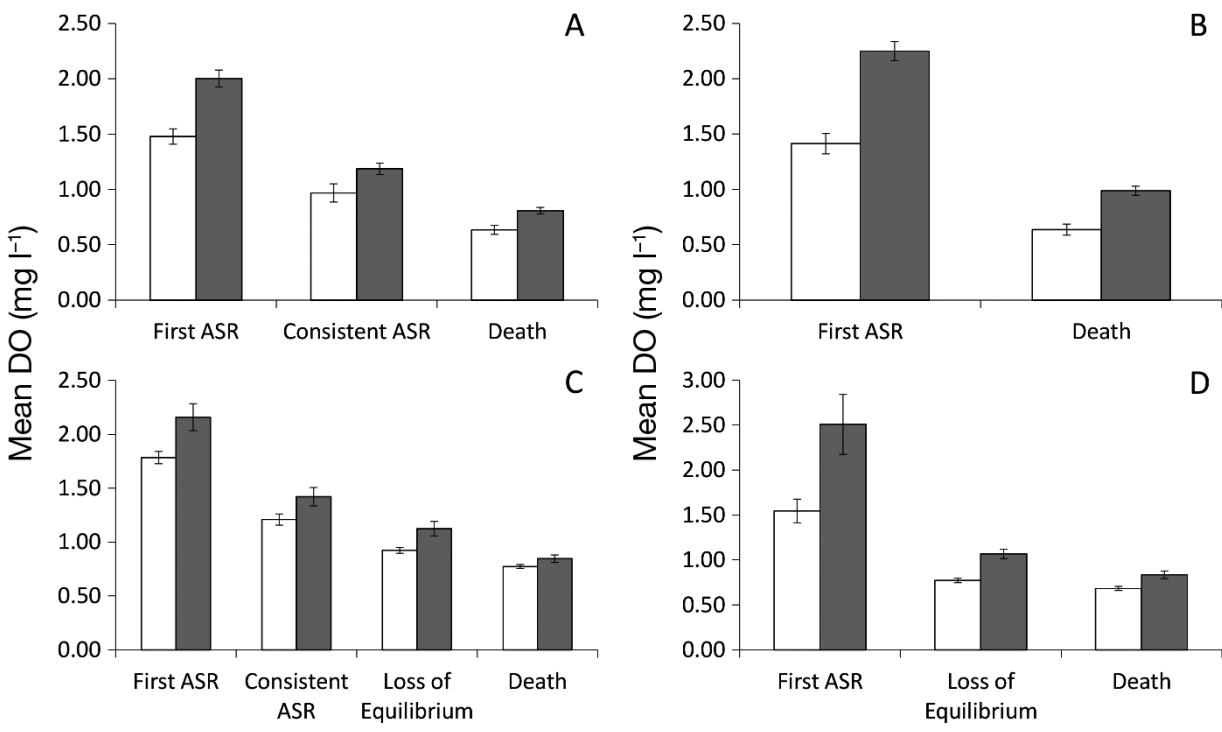

Fig. 2. Mean dissolved oxygen (DO) at which (A) Menidia beryllina in 2014, (B) M. menidia in 2014, (C) M. beryllina in 2015, and (D) M. menidia in 2015 first performed aquatic surface respiration (ASR), consistently performed ASR ( $M$. beryllina only), exhibited loss of equilibrium (2015 only), and died during our trials. White bars represent trials during which we only lowered DO, while gray bars represent trials during which we lowered both DO and pH. Differences between treatments are significant $(\mathrm{p}<$ $0.05)$ for every metric except death of $M$. beryllina in 2015 (panel C). Data are mean $\pm 1 \mathrm{SE}$

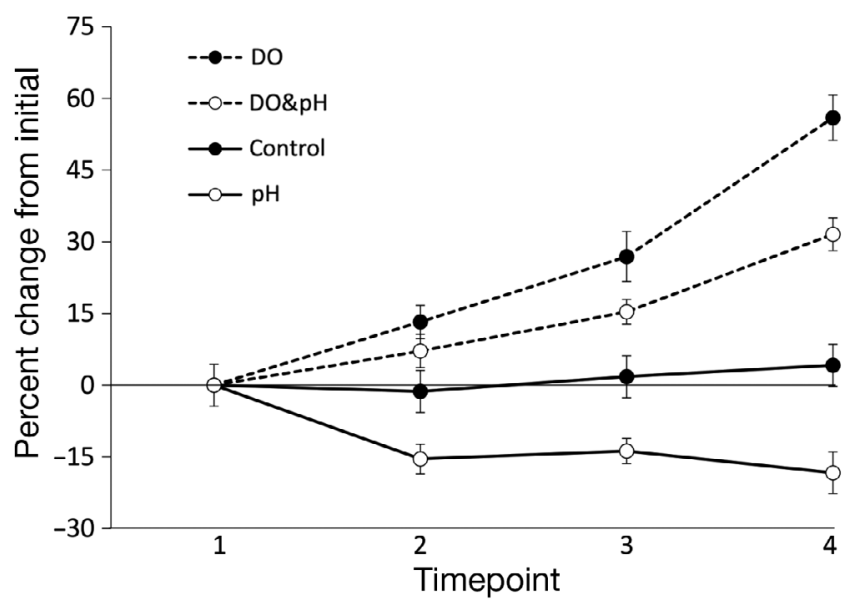

Fig. 3. Percent change in ventilation rate in Menidia beryllina at each timepoint during our ventilation trials. Fish exposed to only low dissolved oxygen (DO) beat their opercula at significantly higher rates than fish exposed to low DO and low $\mathrm{pH}(\mathrm{p}<0.0001)$, and both rates were higher than control fish $(\mathrm{p}<0.0001)$. Fish exposed to only low $\mathrm{pH}$ beat their opercula significantly slower than all other treatments $(p<0.0001)$. Data are mean \pm 1 SE

\section{DISCUSSION}

Our study shows that acidification can make fish more sensitive to hypoxia, causing them to perform ASR and die at higher DO concentrations. These results were somewhat surprising, as adult fishes had been widely expected to be minimally affected by increases in acidification, particularly because their blood is considered to be well buffered against external changes in pH (Melzner et al. 2009, Heuer \& Grosell 2014). The direct link between $\mathrm{CO}_{2}$-driven acidification and death in adult fish found in our study may have an especially strong impact on species inhabiting estuaries and the nearshore, where $\mathrm{pH}$ is more variable and can be lower - and $\mathrm{pCO}_{2}$ higher - than oceanic environments, and acidification from atmospheric $\mathrm{CO}_{2}$ will be combined with respiration-driven acidification. It is possible that acidification may also increase sensitivity to low DO in other habitats, such as oxygen minimum and limiting zones, that are expanding and experiencing increasingly severe deoxygenation with climate change (Keeling et al. 2010).

The combination of hypoxia and increasing acidification may not only cause direct mortality of fishes, but also have important indirect effects on their populations. Performing ASR at higher DO concentrations and for longer periods of time could substantially increase a fish's risk of predation, causing increased mortality under hypoxic conditions that the fish might otherwise survive. Increased acidification could also render uninhabitable some locations that are currently considered marginal, reducing the amount of habitat available for these forage species.

Our investigation of ventilation rates revealed a potential mechanism for the change in ASR behavior and mortality we observed in our study. Fish exposed to low pH actually slowed their ventilation, beating their opercula less frequently than control fish, without any change in DO concentrations (Fig. 3). When we lowered DO as well as $\mathrm{pH}$, fish beat their opercula less than fish exposed to only low DO (Fig. 3), indicating that low $\mathrm{pH}$ is likely suppressing ventilation in some way. It is therefore possible that fish exposed to low DO and low $\mathrm{pH}$ in our ASR trials were 
receiving less water over their gills due to suppressed ventilation, which caused them to perform ASR and die at higher DO concentrations than fish that were not exposed to low $\mathrm{pH}$. Although we consider it likely that there is a mechanistic link between reduced ventilation rates and other responses we measured, we cannot rule out the possibility that the fish were increasing the amplitude of operculum beats (Mikheev et al. 2014) and therefore maintaining or increasing water flow over their gills.

In addition to the decline in ventilation rates we observed under acidification, there are a number of other potential physiological mechanisms that could explain the mortality and performance of ASR at higher DO concentrations which we observed in fish exposed to both acidification and hypoxia. Coping with the physiological problems associated with increased $\mathrm{CO}_{2}$, such as respiratory acidosis (Esbaugh et al. 2012) or increased blood pressure (Perry et al. 1999), may make individuals more susceptible to hypoxia by raising their overall energy requirements. Oxygen levels in the blood could be reduced through Bohr or Root effects, whereby increased $\mathrm{CO}_{2}$ in the bloodstream causes a reduction in the oxygen-binding capability and carrying capacity of hemoglobin (Berenbrink et al. 2011, Zaprudnova et al. 2015). Additionally, receptors on fish gills sense DO concentrations, triggering responses such as ASR or increased ventilation when levels decline past a threshold (Florindo et al. 2006, Zeraik et al. 2013), and most species likely have additional receptors that are sensitive to $\mathrm{CO}_{2}$ or $\mathrm{pH}$, potentially similarly prompting a response (Burleson \& Smatresk 2000, Gilmour 2011, Milsom 2012). Without further study on the location and sensitivity of these receptors, however, the physiological mechanism behind our results is unclear.

This study demonstrates the importance of testing multiple stressors when investigating the impact of climate change and other human effects on marine and estuarine organisms. Fish in our study showed no differences in ASR behavior when only subjected to $\mathrm{pH}$ stress, surviving $\mathrm{pH}$ values as low as 5.8 (the lowest our system could produce) without any loss of equilibrium. If we had investigated only the effect of acidification, we could have concluded that it will have no effect on fish survival, though it likely will have substantial direct and indirect effects when combined with other common stressors.

Finally, though most acidification research has focused on larvae or juveniles, our research indicates that all life stages should be considered when determining how species will respond to climate change, and that there may be no 'refuge' life stage, where an individual becomes relatively immune to acidification. Instead, acidification appears to be a stressor capable of directly and indirectly disrupting all life stages of organisms, even hardy adult estuarine fish living in abiotically stressful environments that experience natural daily fluctuations in $\mathrm{pH}$.

Acknowledgements. We thank A. Collier, D. Comba, and W. McBurney for assistance with field collections and laboratory observations. C. Lord and J. Behrens provided useful comments on the manuscript, and A. Reynolds analyzed our alkalinity samples. Fish were collected under a scientific collection permit from the Maryland Department of Natural Resources Fisheries Service. This work was funded by a Smithsonian Postdoctoral Fellowship award to S.H.M. and a NOAA Center for Sponsored Coastal Ocean Research grant (NA10NOS4780138) to D.L.B.

\section{LITERATURE CITED}

Altieri AH, Gedan KB (2015) Climate change and dead zones. Glob Change Biol 21:1395-1406

Baumann H, Talmage SC, Gobler CJ (2012) Reduced early life growth and survival in a fish in direct response to increased carbon dioxide. Nat Clim Change 2:38-41

Baumann H, Wallace RB, Tagliaferri T, Gobler CJ (2015) Large natural $\mathrm{pH}, \mathrm{CO}_{2}$ and $\mathrm{O}_{2}$ fluctuations in a temperate tidal salt marsh on diel, seasonal, and interannual time scales. Estuaries Coasts 38:220-231

> Berenbrink M, Koldkjaer P, Wright EH, Kepp O, da Silva AJ (2011) Magnitude of the Root effect in red blood cells and haemoglobin solutions of fishes: a tribute to August Krogh. Acta Physiol (Oxf) 202:583-592

Billerbeck JM, Schultz ET, Conover DO (2000) Adaptive variation in energy acquisition and allocation among latitudinal populations of the Atlantic silverside. Oecologia 122:210-219

> Bopp L, Resplandy L, Orr JC, Doney SC and others (2013) Multiple stressors of ocean ecosystems in the 21st century: projections with CMIP5 models. Biogeosciences 10: 6225-6245

Brander SM, Connon RE, He G, Hobbs JA and others (2013) From 'omics to otoliths: responses of an estuarine fish to endocrine disrupting compounds across biological scales. PLoS One 8:e74251

Breitburg DL, Hondorp DW, Davias LA, Diaz RJ (2009) Hypoxia, nitrogen, and fisheries: integrating effects across local and global landscapes. Annu Rev Mar Sci 1: 329-349

Breitburg DL, Salisbury J, Bernhard JM, Cai WJ and others (2015) And on top of all that... coping with ocean acidification in the midst of many stressors. Oceanography (Wash DC) 28:48-61

Burleson ML, Smatresk NJ (2000) Branchial chemoreceptors mediate ventilatory responses to hypercapnic acidosis in channel catfish. Comp Biochem Physiol A 125:403-414

Burrell RB, Keppel AG, Clark VM, Breitburg DL (2016) An automated monitoring and control system for flowthrough co-cyling hypoxia and $\mathrm{pH}$ experiments. Limnol Oceanogr Methods 14:168-185 
Clarke LM, Munch SB, Thorrold SR, Conover DO (2010) High connectivity among locally adapted populations of a marine fish (Menidia menidia). Ecology 91:3526-3537

> DePasquale EL, Baumann H, Gobler CJ (2015) Vulnerability of early life stage Northwest Atlantic forage fish to ocean acidification and low oxygen. Mar Ecol Prog Ser 523: 145-156

> Domenici P, Lefrancois C, Shingles A (2007) Hypoxia and the antipredator behaviours of fishes. Philos Trans R Soc Lond B Biol Sci 362:2105-2121

> Doney SC, Ruckelhaus M, Duffy JE, Barry JP and others (2012) Climate change impacts on marine ecosystems. Annu Rev Mar Sci 4:11-37

Esbaugh AJ, Heuer R, Grosell M (2012) Impacts of ocean acidification on respiratory gas exchange and acid-base balance in a marine teleost, Opsanus beta. J Comp Physiol B 182:921-934

> Ferrari MCO, Dixson DL, Munday PL, McCormick MI, Meekan M, Sih A, Chivers DP (2011) Intrageneric variation in antipredator responses of coral reef fishes affected by ocean acidification: implications for climate change projections on marine communities. Glob Change Biol $17: 2980-2986$

Florindo LH, Leite CAC, Kalinin AL, Reid SG, Milsom WK, Rantin FT (2006) The role of branchial and orobranchial $\mathrm{O}_{2}$ chemoreceptors in the control of aquatic surface respiration in the neotropical fish tambaqui (Colossoma macropomum): progressive responses to prolonged hypoxia. J Exp Biol 209:1709-1715

Frieder CA, Nam SH, Martz TR, Levin LA (2012) High temporal and spatial variability of dissolved oxygen and $\mathrm{pH}$ in a nearshore California kelp forest. Biogeosciences 9: 3917-3930

Fuller C, Bonner J, Page C, Ernest A, McDonald T, McDonald S (2004) Comparative toxicity of oil, dispersant, and oil plus dispersant to several marine species. Environ Toxicol Chem 23:2941-2949

Gilmour $\mathrm{K}$ (2011) The $\mathrm{CO}_{2} / \mathrm{pH}$ ventilatory drive in fish. Comp Biochem Physiol A 130:219-240

> Gobler CJ, DePasquale EL, Griffith AW, Baumann H (2014) Hypoxia and acidification have additive and synergistic negative effects on the growth, survival, and metamorphosis of early life stage bivalves. PLoS One 9:e83648

Heuer RM, Grosell M (2014) Physiological impacts of elevated carbon dioxide and ocean acidification on fish. Am J Physiol Regul Integr Comp Physiol 307:R1061-R1084

Keeling RF, Koertzinger A, Gruber N (2010) Ocean deoxygenation in a warming world. Annu Rev Mar Sci 2:199-229

Kramer DL, McClure M (1982) Aquatic surface respiration, a widespread adaptation to hypoxia in tropical freshwater fishes. Environ Biol Fishes 7:47-55

Kroeker KJ, Kordas RL, Crim RN, Singh GG (2010) Metaanalysis reveals negative yet variable effects of ocean acidification on marine organisms. Ecol Lett 13:1419-1434

MDNR (Maryland Department of Natural Resources) (2014) Eyes on the Bay. www.eyesonthebay.net

Melzner F, Gutowska MA, Langenbuch M, Dupont S and others (2009) Physiological basis for high $\mathrm{CO}_{2}$ tolerance in marine ectothermic animals: pre-adaptation through lifestyle and ontogeny? Biogeosciences 6:2313-2331
Melzner F, Thomsen J, Wolfgang K, Oschlies A and others (2013) Future ocean acidification will be amplified by hypoxia in coastal habitats. Mar Biol 160:1875-1888

Mikheev VN, Pasternak AF, Valtonen ET, Taskinen J (2014) Increased ventilation by fish leads to a higher risk of parasitism. Parasit Vectors 7:281

> Miller GM, Watson SA, Donelson JM, McCormick MI, Munday PL (2012) Parental environment mediates impacts of increased carbon dioxide on a coral reef fish. Nat Clim Change 2:858-861

Milsom WK (2012) New insights into gill chemoreception: receptor distribution and roles in water and air breathing fish. Respir Physiol Neurobiol 184:326-339

Munday PL, Cheal AJ, Dixson DL, Rummer JL, Fabricius KE (2014) Behavioural impairment in reef fishes caused by ocean acidification at $\mathrm{CO}_{2}$ seeps. Nat Clim Change 4: 487-492

Murray CM, Malvezzi A, Gobler CJ, Baumann H (2014) Offspring sensitivity to ocean acidification changes seasonally in a coastal marine fish. Mar Ecol Prog Ser 504:1-11

Perry SF, Fritsche R, Hoagland TM, Duff DW, Olson KR (1999) The control of blood pressure during external hypercapnia in the rainbow trout (Oncorhynchus mykiss). J Exp Biol 202:2177-2190

Rabalais NN, Cai WJ, Carstensen J, Conley DJ and others (2014) Eutrophication-driven deoxygenation in the coastal ocean. Oceanography (Wash DC) 27:172-183

> Rosa R, Seibel BA (2008) Synergistic effects of climaterelated variables suggest future physiological impairment in a top oceanic predator. Proc Natl Acad Sci USA 105:20776-20780

> Smith KJ, Able KW (2003) Dissolved oxygen dynamics in salt marsh pools and its potential impacts on fish assemblages. Mar Ecol Prog Ser 258:223-232

Stefansson ES, Heyes A, Rowe CL (2013) Accumulation of dietary methylmercury and effects on growth and survival in two estuarine forage fish: Cyprinodon variegatus and Menidia beryllina. Environ Toxicol Chem 32:848-856

Stierhoff KL, Targett TE, Grecay PA (2003) Hypoxia tolerance of the mummichog: the role of access to the water surface. J Fish Biol 63:580-592

Tyler RM, Targett TE (2007) Juvenile weakfish Cynoscion regalis distribution in relation to diel-cycling dissolved oxygen in an estuarine tributary. Mar Ecol Prog Ser 333: 257-269

> Vulesevic B, McNeill B, Perry SF (2006) Chemoreceptor plasticity and respiratory acclimation in the zebrafish Danio rerio. J Exp Biol 209:1261-1273

Welch MJ, Watson SA, Welsh JQ, McCormick MI, Munday PL (2014) Effects of elevated $\mathrm{CO}_{2}$ on fish behaviour undiminished by transgenerational acclimation. Nat Clim Change 4:1086-1089

Zaprudnova RA, Kamshilov IM, Chalov YP (2015) Functional properties of hemoglobin during the adaptation of fish to low environmental $\mathrm{pH}$. Inland Water Biol 8: 188-194

Zeraik VM, Belao TC, Florindo LH, Kalinin AL, Rantin FT (2013) Branchial $\mathrm{O}_{2}$ chemoreceptors in Nile tilapia Oreochromis niloticus: control of cardiorespiratory function in response to hypoxia. Comp Biochem Physiol A 166:17-25

Submitted: December 28, 2015; Accepted: March 11, 2016 Proofs received from author(s): April 22, 2016
Editorial responsibility: Konstantinos Stergiou, Thessaloniki, Greece 